Journal of Mathematics and Informatics

Vol. 16, 2019, 119-126

ISSN: 2349-0632 (P), 2349-0640 (online)

Published 4 May 2019

www.researchmathsci.org

DOI: http://dx.doi.org/10.22457/jmi.145av16a11

Journal of

Mathematics and

Informatics

\title{
Research on Online Shopping Behavior of Vietnamese Consumer
}

\author{
Liang-ru Yu ${ }^{1}$, Jing Liu ${ }^{2}$, Jing Chen ${ }^{3}$ and Nguyen Thi Ngoc Trang ${ }^{4}$ \\ ${ }^{1}$ School of Economics and Management \\ Chongqing University of Posts and Telecommunications \\ Chongqing-400065, Chongqing, China. E-mail: yuliangru@qq.com \\ ${ }^{2}$ Information and Library Center \\ Chongqing Medical and Pharmaceutical College \\ Chongqing - 401331, Chongqing, China. E-mail: 717139038@qq.com \\ ${ }^{3}$ School of Economics and Management \\ Chongqing University of Posts and Telecommunications \\ Chongqing - 400065, Chongqing, China. E-mail: chenjing@ @qupt.edu.cn \\ ${ }^{4}$ School of Economics and Management \\ Chongqing University of Posts and Telecommunications \\ Chongqing - 400065, Chongqing, China. E-mail: 3454647833@qq.com \\ ${ }^{2}$ Corresponding author
}

Received 15 April 2019; accepted 2 May 2019

Abstract. With the progress of informatization in Vietnam, the Vietnamese have accepted online shopping, and the research on online shopping behavior of Vietnamese consumers has important theoretical and practical significance. Based on the "four streams" of ecommerce (flow of information, flow of trading, flow of financing and flow of goods), this paper conducts an empirical analysis of Vietnamese consumers' online shopping behavior. we found that education and monthly income have a significant impact on the amount of consumers' online shopping, while flow of information and flow of goods have a significant positive effect on consumers' online shopping frequency.

Keywords: online shopping behavior; flow of information; flow of trading; flow of financing; flow of goods

\section{AMS Mathematics Subject Classification (2010): 62P25}

\section{Introduction}

With the rapid development of information technology and network technology, the Internet is not only a communication network, but also an important channel for consumer transactions. In recent years, the number of Internet users in Vietnam has risen rapidly, and online shopping is gradually becoming an indispensable shopping channel for the Vietnamese. Now Vietnam is one of the fastest growing countries of B2C ecommerce market in Southeast Asia. According to the latest report from the Vietnamese market research institute Q\&Me, the e-commerce scale in Vietnam reached US\$6.2 


\section{Liang-ru Yu, Jing Liu, Jing Chen and Nguyen Thi Ngoc Trang}

billion by 2017. It is expected that this value will rise to US $\$ 10$ billion by 2020 . According to the report of the United Nations Conference on Trade and Development, the proportion of online shoppers increased from $10.79 \%$ in 2013 to $16.23 \%$ in 2018 . The above data shows that the number of online shopping consumers in Vietnam is increasing, and the demand for online shopping is growing. Therefore, it is necessary to study Vietnamese consumers' online shopping behavior.

When making online shopping, the consumer decides whether to purchase the goods by collecting product information, promotion information, seller reputation, etc. This process is called flow of information. The transfer of funds after the purchase decision is called flow of financing, including the process of payment, transfer, and so on. Then deliver the goods to the consumer through flow of goods. All of the above processes are based on the transfer of goods from the production to the consumer sector. This process is called flow of trading. It can be seen that every transaction in e-commerce includes four basic flows, namely flow of information, flow of trading, flow of financing and flow of goods [1].

In the existing research on the factors affecting the online shopping behavior of Vietnamese consumers, Do et al. found that perceived usefulness, perceived ease of use, perceived transaction security and other demographic factors (age and income) are important factors to affect the willingness of Vietnamese online consumers to purchase [2]. Dang and Pham proposed that consumers' perception of web design is positively related to users' reliability, privacy, customer service and purchase intention [3]. Mai et al. believe that distribution fairness, customer interface quality, perceived security, perceived usefulness and trust are significant predictors of customer satisfaction, and customer satisfaction plays a crucial role in consumer spending intentions [4]. Reviewing the existing literature, the research on Vietnamese consumers' willingness to purchase online is mostly from one or two aspects of flow of information, flow of trading, flow of financing and flow of goods, but lacks the research from the whole four direction. Therefore, this paper uses flow of information, flow of trading, flow of financing and flow of goods to explain the online shopping behavior of Vietnamese consumers.

\section{Hypotheses}

\subsection{Flow of information}

Flow of information refers to all information acquisition, identification, processing and application activities carried out by buyers and sellers in order to facilitate transactions for their own benefit in e-commerce transactions. Product information plays an important role in consumer purchasing decisions [5]. In the process of online purchase, all consumers have to collect information. Information becomes the basis for consumers to conduct brand evaluation and purchase decisions, which affect the realization of the entire purchase process. Consumers make online shopping decisions through information search and scheme comparison [6]. Therefore, this paper proposes the following hypotheses:

H1: Flow of information has a positive effect on online shopping behavior. 


\section{Research on Online Shopping Behavior of Vietnamese Consumer}

\subsection{Flow of trading}

Flow of trading is a kind of buying and selling or a kind of trade activity process, through which the transfer of ownership of goods takes place. In online shopping, the process of transferring ownership of goods is very simple. As long as the consumer confirms the receipt and payment, the ownership of the goods is transferred immediately. Therefore, this paper believes that because of the ease of transfer of goods' ownership, consumers will pay more attention to the safety of online shopping. Consumers will require merchants to provide relevant trade vouchers and other security measures. Therefore, this paper proposes the following hypotheses:

H2: Flow of trading has a positive effect on online shopping behavior.

\subsection{Flow of financing}

Flow of financing depends on the development of e-commerce business by traditional banks. Banks are the core of flow of financing and the link to ensure the smooth progress of the trade process. Flow of financing is a very important part of e-commerce activities, and the flow of financing can guarantee the completion of the transaction. Simply, flow of financing is the process of capital exchange between enterprises and suppliers, retailers and consumers in the process of transferring goods, and ownership of goods. At present, most consumers in Vietnam are still accustomed to cash on delivery, but many banks have launched online banking services and are trying to attract new customers [7], so the flow of financing of online shopping in Vietnam is worth studying. Therefore, this paper proposes the following hypotheses:

H3: Flow of financing has a positive effect on online shopping behavior.

\subsection{Flow of goods}

Flow of goods refers to the displacement of goods in space and time, including the circulation of procurement and distribution, logistics processing, warehousing and packaging. Its main performance characteristics are logistics. Logistics can improve the efficiency of online shopping, coordinate the goals of online shopping, and expand the market scope of e-commerce. Based on this, the development of online shopping depends on logistics, which must synchronized with online shopping, and cope with changes of online shopping needs [8]. Without logistics services, online shopping cannot be completed successfully [9]. The latest delivery time acceptable to consumers, service evaluation of logistics staff and logistics freight are the main factors directly reflecting consumers' attitude towards logistics. Therefore, this paper proposes the following hypotheses:

H4: Flow of goods has a positive effect on online shopping behavior.

\section{Methods}

\subsection{Sample and procedure}

Data collection. Use Google tools (Google Docs) to upload questionnaires and send them through online tools such as email, social networks, (forums, Facebook, etc.). A total of 
Liang-ru Yu, Jing Liu, Jing Chen and Nguyen Thi Ngoc Trang

400 questionnaires were collected, and 319 were valid after screening. The sample characteristics of Vietnamese consumers are shown in Table 1.

Table 1: Sample characteristics

\begin{tabular}{|c|c|c|c|}
\hline $\begin{array}{c}\text { Personal } \\
\text { characteristics }\end{array}$ & Categories & $\begin{array}{c}\text { Number of } \\
\text { Questionnaires }(n=319)\end{array}$ & $\begin{array}{c}\text { Percentage } \\
(\%)\end{array}$ \\
\hline \multirow{2}{*}{ Gender } & Male & 138 & 43.3 \\
\hline & Female & 181 & 56.7 \\
\hline \multirow{4}{*}{$\begin{array}{c}\text { Age } \\
\text { (Years) }\end{array}$} & Below 18 & 15 & 4.7 \\
\hline & $18-25$ & 185 & 58 \\
\hline & $26-45$ & 98 & 30.7 \\
\hline & Above 46 & 21 & 6.6 \\
\hline \multirow{4}{*}{ Education } & Bachelor Below & 41 & 12.9 \\
\hline & Bachelor & 186 & 58.3 \\
\hline & Master & 79 & 24.8 \\
\hline & Master Above & 13 & 4.1 \\
\hline \multirow{5}{*}{ Career } & Student & 62 & 19.4 \\
\hline & Teacher & 55 & 17.2 \\
\hline & $\begin{array}{c}\text { Enterprise and } \\
\text { Company Personnel }\end{array}$ & 150 & 47 \\
\hline & $\begin{array}{c}\text { Government and } \\
\text { Institutions } \\
\end{array}$ & 24 & 7.5 \\
\hline & Other & 28 & 8.8 \\
\hline \multirow{4}{*}{$\begin{array}{c}\text { Income } \\
\text { (VND/Month) }\end{array}$} & Below 3.5 million & 43 & 13.5 \\
\hline & $\begin{array}{c}3.5 \text { million }-8.5 \\
\text { million }\end{array}$ & 103 & 32.3 \\
\hline & $\begin{array}{l}8.5 \text { million - } 14 \\
\text { million }\end{array}$ & 131 & 41.1 \\
\hline & Above 14 million & 42 & 13.2 \\
\hline \multirow{2}{*}{$\begin{array}{c}\text { Online shopping } \\
\text { experience }\end{array}$} & Yes & 305 & 95.6 \\
\hline & No & 14 & 4.4 \\
\hline
\end{tabular}

\subsection{Measures}

Questionnaire design is mainly from the five dimensions of personal information characteristics, flow of information, flow of trading, flow of financing and flow of goods, and the Likert five-level scale is used to measure. After the questionnaire was collected, 
Research on Online Shopping Behavior of Vietnamese Consumer

the data was encoded and entered. SPSS 23.0 and regression analysis were used to analyse the data.

Dependent variable: monthly online shopping expenditure, online shopping frequency. Monthly online shopping expenditures and online shopping frequency are intuitive reflections of consumers' online shopping behaviour. Therefore, this paper conducted two regression analysis, which used monthly online shopping expenditure and online shopping frequency as the dependent variables, and analysed the regression results.

\section{Results}

This paper uses regression analysis to test the hypothesis. The software used is SPSS 23.0. Regression analysis with monthly online shopping expenditure as dependent variable is shown in Model 1 in Table 2, and regression analysis with online shopping frequency as dependent variable is shown in Model 2 in Table 2. The variance inflation factor (VIF) of each variable is much less than 10, indicating that the multicollinearity is not serious and the analysis results are reliable.

Table 2: Regression analysis of Vietnamese consumers' online shopping

\begin{tabular}{|c|c|c|}
\hline Variable & $\begin{array}{c}\text { Dependent variable: } \\
\text { Monthly online } \\
\text { shopping } \\
\text { expenditure } \\
\end{array}$ & $\begin{array}{c}\text { dependent } \\
\text { variable: } \\
\text { Online shopping } \\
\text { frequency }\end{array}$ \\
\hline & Model 1 & Model 2 \\
\hline Constant & $(5.424)$ & (3.894) \\
\hline Bachelor Below & $\begin{array}{l}0.163^{* *} \\
(2.630)\end{array}$ & $\begin{array}{c}-0.074 \\
(-1.210)\end{array}$ \\
\hline Bachelor Above & $\begin{array}{c}0.043 \\
(0.725)\end{array}$ & $\begin{array}{c}-0.037 \\
(-0.641)\end{array}$ \\
\hline Career & $\begin{array}{c}0.033 \\
(0.366)\end{array}$ & $\begin{array}{c}0.083 \\
(0.942)\end{array}$ \\
\hline Age & $\begin{array}{c}0.007 \\
(0.121)\end{array}$ & $\begin{array}{c}0.010 \\
(0.172)\end{array}$ \\
\hline Monthly Income & $\begin{array}{l}0.139 * \\
(2.172)\end{array}$ & $\begin{array}{c}-0.094 \\
(-1.493) \\
\end{array}$ \\
\hline $\begin{array}{l}\text { Focus on promotional information during } \\
\text { online shopping }\end{array}$ & $\begin{array}{c}-0.013 \\
(-0.212)\end{array}$ & $\begin{array}{l}0.136^{*} \\
(2.209)\end{array}$ \\
\hline Online shopping security & $\begin{array}{c}0.074 \\
(1.209)\end{array}$ & $\begin{array}{c}0.004 \\
(0.072)\end{array}$ \\
\hline $\begin{array}{c}\text { During the online shopping process, you ask } \\
\text { the merchant to provide relevant trade } \\
\text { certificates. }\end{array}$ & $\begin{array}{c}-0.105 \\
(-1.682)\end{array}$ & $\begin{array}{c}0.106 \\
(1.208)\end{array}$ \\
\hline
\end{tabular}


Liang-ru Yu, Jing Liu, Jing Chen and Nguyen Thi Ngoc Trang

\begin{tabular}{|c|c|c|} 
Payment process during online shopping & $\begin{array}{c}-0.054 \\
(-0.921)\end{array}$ & $\begin{array}{c}0.106 \\
(1.844)\end{array}$ \\
\hline Refund process during online shopping & -0.027 & 0.106 \\
& $(-0.302)$ & $(1.208)$ \\
\hline The latest delivery time limit acceptable & 0.035 & -0.050 \\
during online shopping & $(0.609)$ & $(-0.895)$ \\
\hline How to evaluate the service of logistics staff & -0.086 & $0.167 * *$ \\
during online shopping & $(-1.491)$ & $(2.940)$ \\
\hline Pay attention to logistics freight in online & 0.013 & 0.051 \\
shopping & $(0.216)$ & $0.863)$ \\
\hline R2 & 0.058 & 0.094 \\
\hline F & 1.452 & $2.432^{* *}$ \\
\hline$\Delta \mathrm{R} 2$ & 0.058 & 0.094 \\
\hline F of $\Delta$ R2 & 1.452 & $2.432^{* *}$ \\
\hline Max VIF & 2.612 & 2.612 \\
\hline
\end{tabular}

Note. 1) $t$ value was in parentheses; 2) coefficient had been standardized; 3) * $\mathrm{p}<0.05$, $* * \mathrm{p}<0.01, * * * \mathrm{p}<0.001$.

The analysis results of Model 1 in Table 2 show that the $\mathrm{P}$ values below the bachelor $(\mathrm{P}=0.009)$ and monthly income $(\mathrm{P}=0.031)$ are both less than 0.05 . Therefore, for Vietnamese consumers, education and monthly income have a significant positive impact on consumers' online shopping amount. Consumers below the bachelor (compared to above the bachelor) spend more money on online shopping, and consumers with higher monthly incomes are more willing to spend money on online shopping. Most of the Vietnamese young people are bachelor below and they are willing to spend money on online shopping. This is a feature of Vietnamese consumers' online shopping. In this regression analysis, $\mathrm{H} 1, \mathrm{H} 2, \mathrm{H} 3$, and $\mathrm{H} 4$ were not verified.

The analysis results of Model 2 in Table 2 show that the $\mathrm{P}$ value of the promotion information in the online shopping process $(\mathrm{P}=0.028)$ and the service evaluation of the logistics staff during the online shopping process $(\mathrm{P}=0.004)$ are all less than 0.05 . Therefore, for Vietnamese consumers, the attention of promotion information and the service evaluation of the logistics staff during the online shopping process have significant positive impacts on the consumer online shopping frequency. The consumers who are more concerned about promotion information and positive service evaluation have higher frequency of online shopping. Paying attention to the promotion information in the online shopping process belongs to the flow of information. The service evaluation of the logistics staff in the online shopping process belongs to the flow of goods. Therefore, $\mathrm{H} 1$ and $\mathrm{H} 4$ are supported, and $\mathrm{H} 2$ and $\mathrm{H} 3$ are not supported.

\section{Conclusion}

Based on the four flows (flow of information, flow of trading, flow of financing and flow of goods), this paper studies the online shopping behavior of Vietnamese consumers. Through the empirical analysis of Vietnamese consumers' online shopping behavior, it is found that the education and monthly income have a significant impact on the online 


\section{Research on Online Shopping Behavior of Vietnamese Consumer}

shopping amount of consumers. Paying attention to the promotion information and the service evaluation of the logistics staff during the online shopping process have a significant positive impact on the consumer online shopping frequency, that is, flow of information and flow of goods have a significant impact on consumer online shopping frequency.

Compared with the existing research, the theoretical significance of this paper is: First, it has deepened the research on the online shopping behavior of Vietnamese consumers. Previous scholars have done some research on Vietnamese consumers' online shopping, but their research is relatively general and not detailed enough. There are relatively few studies on the Vietnamese e-commerce market. Different from previous studies, this paper has targeted the online shopping behavior of Vietnamese consumers. Second, supplement and improve the theoretical study of Vietnamese consumers' online shopping behavior. There is a lack of research on the online shopping behavior of Vietnamese consumers using complete four flows. This paper explores the impact of flow of information, flow of trading, flow of financing and flow of goods on Vietnamese consumers' online shopping behavior.

The practical significance of this paper is to accurately grasp the needs of Vietnamese consumers and help Vietnamese e-commerce companies to design marketing strategies. First, invest more in promotional information. The more promotional information Vietnamese consumers pay attention to online shopping, the higher their shopping frequency is. So Vietnamese e-commerce companies should release more attractive promotional information. Second, improve the quality of logistics services. Because Vietnamese consumers will pay attention to the services of logistics workers, Vietnamese e-commerce companies should establish clear rules and regulations to regulate the services of logistics workers. If consumers are not satisfied with their services, they should take corresponding measures to make positive service evaluation.

Acknowledgements. This work is supported by the Social Science Fund of Chongqing University of Posts and Telecommunications (No. K2015-11).

\section{REFERENCES}

1. W.Ying, S.Dayong, Multi-agent framework for third party logistics in E-commerce, Expert Systems with Applications, 29(2) (2005) 431-436.

2. T.Do, T.Nguyen, C.Nguyen, Online shopping in an emerging market: the critical factors affecting customer purchase intention in Vietnam, Journal of Economics and Management Sciences, 2(2) (2019) 1-11.

3. V.T.Dang, T.L.Pham, An empirical investigation of consumer perceptions of online shopping in an emerging economy, Asia Pacific Journal of Marketing and Logistics, 30(4) (2018) 952-971.

4. N.T.T.Mai, T.Yoshi, N.P.Tuan, Determinants of online customer satisfaction in an emerging market - a mediator role of trust, Contemporary Management Quarterly, 13(1) (2014) 8-30.

5. T.Zhang, G.Li, K.K.Lai, J.W.K.Leung, Information disclosure strategies for the intermediary and competitive sellers, European Journal of Operational Research, 271(3) (2018) 1156-1173.

6. N.Li, P.Zhang, Consumer online shopping attitudes and behavior: an assessment of 
Liang-ru Yu, Jing Liu, Jing Chen and Nguyen Thi Ngoc Trang research, AMCIS 2002 Proceedings, (2002) 74.

7. J.S.Wang, T.S.Pho, Drivers of customer intention to use online banking: An empirical study in Vietnam, African Journal of Business Management, 3 (11) (2009) 669-677.

8. H.Lim, N.Shiode, The impact of online shopping demand on physical distribution networks: a simulation approach, International Journal of Physical Distribution \& Logistics Management, 41(8) (2011) 732-749.

9. Y.Feng, B.Zheng, J.Tan, Exploratory study of logistics service quality scale based on online shopping malls, Journal of Zhejiang University-SCIENCE A, 8(6) (2007) 926931. 